\title{
PERBANDINGAN ALGORITMA DSATUR DAN ALGORITMA VERTEX MERGE UNTUK MENENTUKAN CHANNEL WLAN
}

\author{
Handrizal \\ Dosen STIKOM Tunas Bangsa Pematangsiantar, Sumatera Utara-Indonesia \\ Jalan Sudirman Blok A No. 1, 2, 3 Pematangsiantar \\ E-mail : Handrizal_tanjung@yahoo.com
}

\begin{abstract}
Abstrak
Seiring dengan perkembangan teknologi maka kebutuhan akan ketersedian akses internet melalui wireless lokal area network (WLAN) akan ikut meningkat. Semakin bertambahnya jumlah WLAN maka akan mempengaruhi kualitas dari WLAN itu sendiri, untuk itu diperlukan cara mengatasi masalah tersebut. Algoritma Dsatur dan algoritma Vertex Merge adalah dua buah algoritma yang dapat digunakan untuk membantu masalah diatas. Kedua algoritma ini bekerja berdasarkan konsep pewarnaan graf, setiap vertex dalam graf dianalogikan sebagai akses point dalam WLAN. Hasil penelitian ini menunjukkan bahwa Algoritma Vertex Merge bekerja lebih baik dibandingkan dengan algoritma Dsatur dengan menghasilkan lebih sedikit jumlah channel yang diperlukan.
\end{abstract}

Kata kunci: Dsatur; vertex merge; channel; WLAN

\section{Pendahuluan}

Kebutuhan akan jaringan wireless sekarang ini terus meningkat, baik dirumah, kantor, bahkan tempat-tempat umum seperti restoran, hotel, dan dan bahkan pusat-pusat kota yang telah banyak dilengkapi dengan Akses Point (AP) untuk menawarkan konektivitas wireless. Pada saat yang sama kepadatan peningkatan jalur akses WLAN mulai menyoroti kekurangan dari standar IEEE 802,11 . Sampai saat ini belum ada metode standar untuk alokasi channel pada akses point WLAN. Hal ini mengarah pada situasi di mana sebagian besar AP menggunakan pengaturan channel secara default, menyebabkan penggunaan sangat tidak efisien dari spektrum yang sudah padat. Situasi ini penting pada pita $2,4 \mathrm{GHz}$, karena hanya sedikit jumlah non-overlapping channel WLAN yang tersedia dan masalah berdekatan dengan beberapa teknologi wireless lainnya.

Kekurangan yang terdapat pada Industrial Scientific and Medical (ISM) band $2.4 \mathrm{GH}$ menurut badan pengawas Eropa adalah hanya disediakan 13 channel, yaitu dimulai dari $2.412 \mathrm{GHz}$ (channel 1) sampai dengan $2.472 \mathrm{GHz}$ (channel13), seperti ditunjukkan pada Gambar 1. Masing-masing channel diberi jarak 5MHz, sedangkan lebar bandwidth sinyal adalah sekitar $24 \mathrm{MHz}$, sehingga hanya memiliki sebanyak tiga channel yang tidak overlapping (1, 6 dan 11), seperti ditujukkan pada gambar 2 . Dengan semakin berkembangnya teknologi wireless dan semakin pesatnya pertumbuhan kebutuhan akan adanya jaringan wireless, maka terlihat jelas bahwa di daerah dengan kepadatan besar, tiga buah channel yang tidak overlapping akan tidak cukup untuk mengatasinya

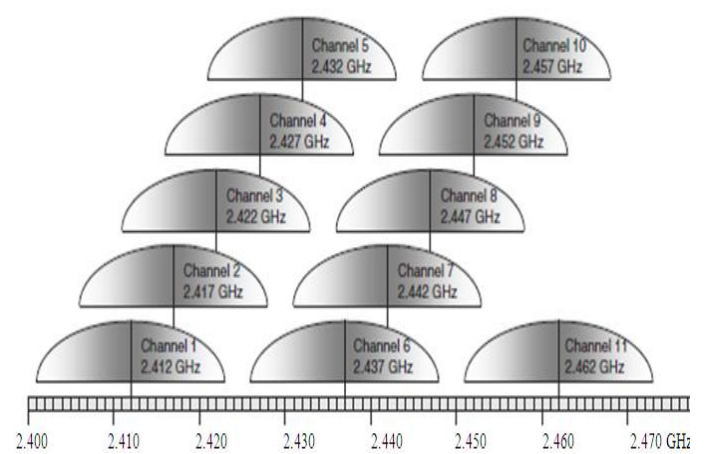


Gambar 1. Alokasi channel pada wireless (Handrizal, 2012)

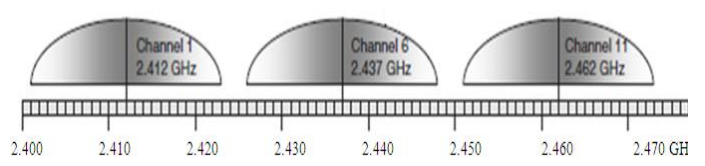

Gambar 2. Channel yang tidak overlapping pada wireless (Handrizal, 2012)

Penggunaan channel dengan overlapping (misalnya, channel 1 dan channel 2) dalam ruang fisik yang sama akan menyebabkan interferensi antara sistem, sehingga akan menyebabkan penurunan drastis pada throughput.

Beberapa artikel penelitian telah dipublikasikan tentang alokasi channel. Diantara mereka adalah Al Mamun dkk. (2009), Andre (2005), Duan dkk (2010), Ming, H. dkk (2009), Juhos (2006), Riihijarvi, dkk. (2006). Penelitianpenelitian itu mengungkapkan bahwa alokasi channel untuk wireless adalah salah satu masalah saat ini yang masih belum terpecahkan.

\section{Landasan Teori}

Pada bagian ini akan bahas mengenai alokasi channel untuk WLAN dalam hal teori pewarnaan graf. Menurut (Diestel, 2010) yang menarik dalam konteks alokasi channel misalkan, diberi graf sederhana $G=(V, E)$, yaitu graf yang terdiri dari satu himpunan vertex $\mathrm{V}$ dan himpunan edge E. Loop dan multiedge antara vertex tidak diperbolehkan. Kemudian pewarnaan vertex dari $G$ adalah pemetaan: $V(G) \rightarrow$ $F$, dimana $F$ adalah satu himpunan warna, biasanya beberapa bagian kecil dari bilangan bulat positif. Sebuah vertex dapat diwarnai, jika $\mathrm{C}\left(\mathrm{V}_{\mathrm{i}}\right)=\mathrm{C}\left(\mathrm{V}_{\mathrm{j}}\right)$ untuk semua $V_{i}$ dan $V_{j}$ berdekatan (yaitu, untuk vertex yang terhubung dengan sebuah edge. Dalam pewarnaan graf, tidak hanya sekedar mewarnai vertexvertex dengan warna yang berbeda dengan warna vertex tetangganya saja, akan tetapi juga diinginkan agar jumlah warna yang digunakan sesedikit mungkin. Jumlah warna minimum yang dapat digunakan untuk mewarnai vertexvertex disebut bilangan kromatik dari graf $\mathrm{G}$ yang disimbolkan dengan $\chi(G)$.

\section{Interferensi Graf}

Sekarang akan bahas mengenai alokasi channel dalam hal terminologi yang telah diperkenalkan pada bagian sebelumnya. Misalkan, $\left\{\mathrm{v}_{\mathrm{i}}\right\}$ adalah himpunan dari akses point, itu akan membentuk sebuah grafik gangguan $\mathrm{G}=$ (VG, EG) sebagai berikut. Himpuan vertex $\mathrm{V}$ hanya diidentifikasi dengan himpunan $\left\{\mathrm{v}_{\mathrm{i}}\right\}$. Himpunan edge $\mathrm{E}$ dibangun dengan gabungan dari pasangan $\left\{\mathrm{v}_{\mathrm{k}}, \mathrm{v}_{\mathrm{l}}\right\}$ dari vertex, yang sesuai dengan akses point $\mathrm{v}_{\mathrm{k}}$ dan $\mathrm{v}_{1}$ yang akan mengganggu lalu lintas radio masing-masing jika mereka harus menggunakan channel yang sama. Akhirnya $F$ merupakan himpunan "warna", untuk menjadi koleksi channel yang tersedia untuk akses point. Tentu saja ukuran himpunan warna sangat tergantung dari teknologi dan undangundang yang berlaku disuatu negara. Di kebanyakan negara Eropa, $F=\{1,2 \ldots$ 13\} sedangkan sub himpunan $F^{\prime}=\{1,6$, 11\} untuk channel yang tidak overlapping.

\section{Matrix Kedekatan}

Misalkan $\mathrm{G}$ adalah graf dengan $\mathrm{m}$ vertex dan misalkan vertex telah diurutkan, katakanlah, vi, vj, ..., vm. Seperti ditunjukkan pada Gambar. 3. Kemudian Matrik kedekatan A $(\mathrm{G})=$ [aij] dari graf $\mathrm{G}$ adalah matrik $\mathrm{m} \times \mathrm{m}$ yang didefinisikan dengan: 


\section{Gambar 3. Contoh graf}

Matrik kedekatan A dari graf G tidak tergantung pada urutan dari vertex $G$, yaitu, pengurutan yang berbeda dari vertex menghasilkan matrik kedekatan yang berbeda. Namun, setiap dua matrik berdekatan tersebut terkait erat, dimana yang satu dapat diperoleh dari yang lain hanya dengan menukar baris dan kolom, seperti terlihat pada gambar 4 .

$$
a_{i j}=\left\{\begin{array}{l}
1, v_{i} v_{j} \in E_{G} \\
0, v_{i} v_{j} \notin E_{G}
\end{array}\right.
$$

Gambar 4. Matrik kedekatan graf

\section{Metode Penelitian}

Pada bagian ini akan dibahas dua buah metode yang akan dibandingkan dalam penelitian ini yaitu algoritma Dsatur dan algoritma Vertex Merge

\section{Algoritma Dsatur}

Algoritma Degree of Saturation (Dsatur) diperkenalkan oleh Brelaz pada tahun 1979 (Brelaz, 1979). Algoritma Dsatur adalah algoritma pewarnaan graf berdasarkan derajat (degree) suatu vertex. Pada tahun 2006, Riihijarvi (Riihijarvi, 2006) telah menerapkan algoritma Dsatur untk menentukan alokasi channel. Algoritma ini menentukan channel berdasarkan degree paling tinggi dari pada AP. Algoritma ini tidak selalu memberikan jumlah minimum channel yang diperlukan untuk AP. Algoritma ini hanya cukup praktis untuk graf sederhana. Namun, algoritma ini tidak cukup praktis untuk graf yang lebih komplek. Berikut ini adalah langkah-langkah algoritma Dsatur selengkapnya:

1. Susun vertex berdasarkan penurunan jumlah derajat.

2. Warnai vertex berderajat maksimal dengan warna 1
3.Pilih vertex dengan derajat kejenuhan maksimal. Jika ada yang sama, pilih vertex dengan derajat maksimal dalam subgraph yang belum diwarnai.

4. Warnai vertex yang sudah dipilih dengan warna yang paling memungkinkan

5.Jika seluruh vertex sudah diwarnai, berhenti. Jika tidak, kembali ke langkah 3.

\section{Algoritma Vertex Merge}

\begin{tabular}{l|llll}
\multicolumn{1}{c}{} & $\mathrm{v}_{1}$ & $\mathrm{v}_{2}$ & $\mathrm{v}_{3}$ & $\mathrm{v}_{4}$ \\
\cline { 2 - 5 } $\mathrm{v}_{1}$ & 0 & 1 & 1 & 0 \\
$\mathrm{v}_{2}$ & 1 & 0 & 0 & 1 \\
$\mathrm{v}_{3}$ & 1 & 0 & 0 & 1 \\
$\mathrm{v}_{4}$ & 0 & 1 & 1 & 0
\end{tabular}

Algoritma Vertex Merge adalah algoritma yang didasarkan pada deterministik, karena bertentangan dengan algoritma acak yang banyak diusulkan. Hal ini diperlukan karena akses point secara alami harus setuju pada channel yang telah dialokasikan (Handrizal, 2012).

Algoritma Vertex Merge menggunakan beberapa metode heuristik untuk memilih vertex yang akan diwarnai, Heuristik yang digunakan oleh algoritma ini adalah untuk menemukan sub himpunan dari vertex dengan derajat tertinggi, yaitu, vertex dengan jumlah perbedaan edge terbesar dengan tetangga. Jika sub himpunan ini hanya berisi satu vertex, ia dipilih menjadi berwarna. Jika lebih dari satu vertex tetap di himpunan, pemilihan ini kemudian dibuat dalam urutan penurunan jumlah tetangga yang belum diwarnai. Berikut ini adalah langkah demi langkah algoritma Vertex Merge:

1. Susun vertex berdasarkan penurunan jumlah derajat.

2. Pilih vertex pertama yang belum diwarnai didalam himpunan.

3. Warnai vertex yang sudah dipilih dengan warna yang paling memungkinkan 
4. Gabungkan vertex dengan vertex pertama yang tidak bertetangga.

5. Warnai vertex yang sudah dipilih dengan warna yang sama. Jika tidak ada lagi vertex yang tidak bertetangga, kembali kelangkah 2.

6. Jika seluruh vertex sudah diwarnai. Berhenti. Jika tidak, kembali ke langkah 2.

\section{Hasil dan Pembahasan}

Pada bagian ini akan dibahas hasil dan diskusi dari simulasi perbandingan algoritma Dsatur dan
algoritmaVertex Merge dengan inputan berupa tiga buah graf komplek yaitu graf1 dengan 10 vertex yang diberi label $V=\{1,2,3,4,5,6,7,8,9,10\}$, graf2 dengan 14 vertex yang diberi label $V=$ $\{1,2,3,4,5,6,7,8,9,10,11,12,13$, $14\}$, dan graf3 dengan 17 vertex yang diberi label $V=\{1,2,3,4,5,6,7,8,9$, $10,11,12,13,14,15,16,17\}$, untuk setiap vertex didalam graf merupakan akses point didalam wireless.

Hasil simulasi dengan inputan berupa tiga buah graf komplek akan di tampilkan pada tabel 1 dibawah ini:

Tabel 1: Input graf untuk simulasi

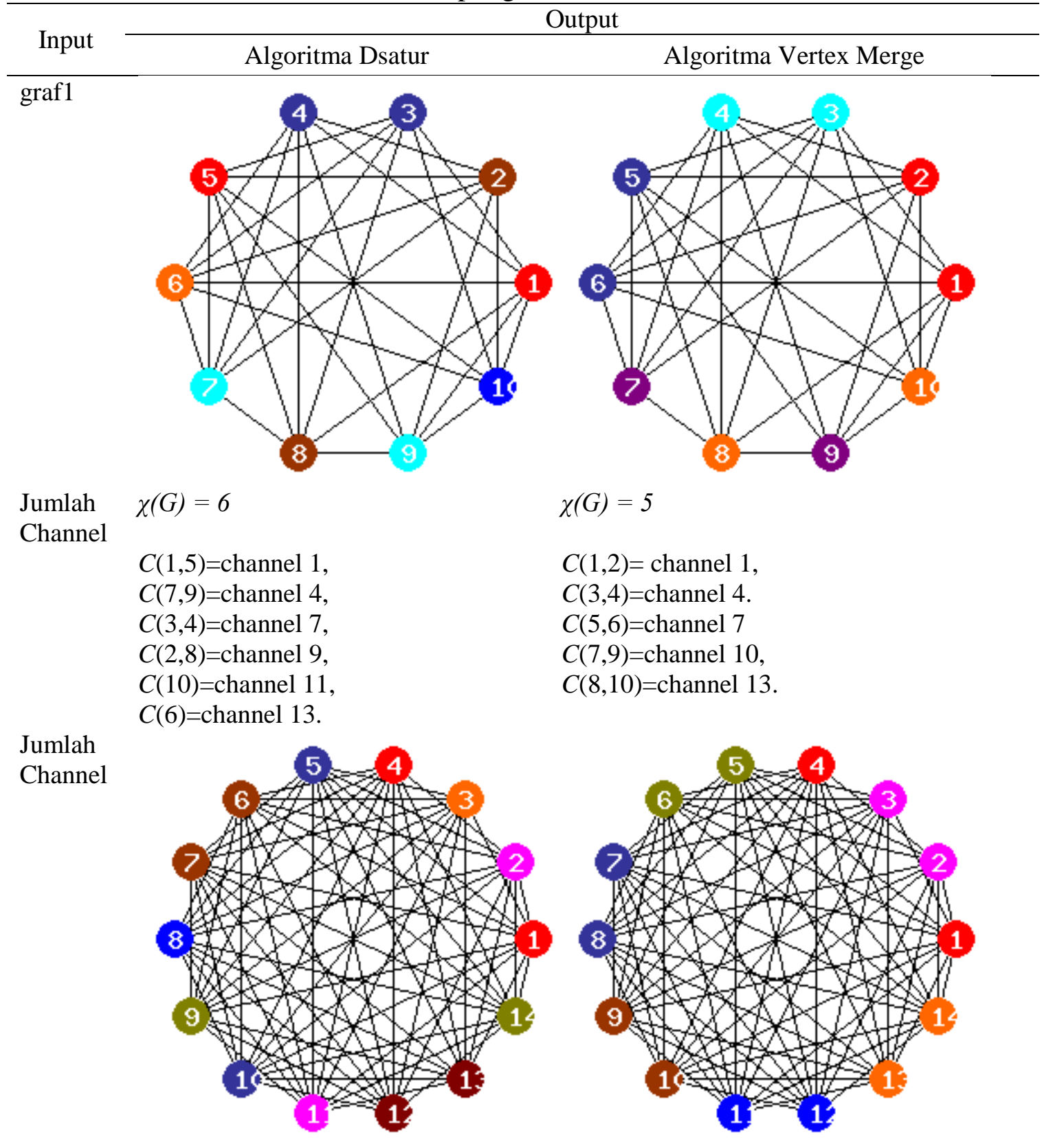




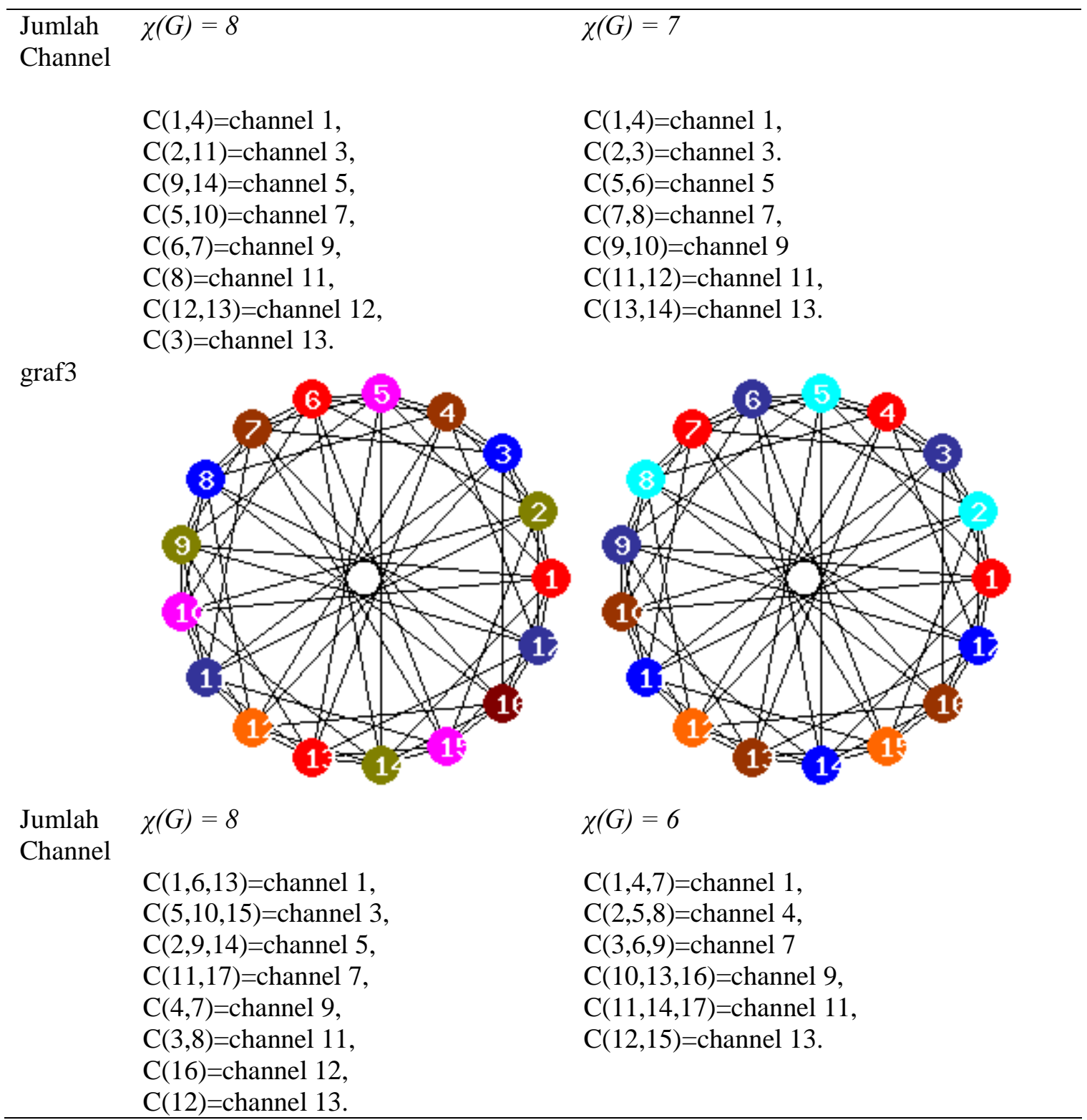

Dari hasil simulasi tiga buah graf pada tabel 1 dapat dilihat bahwa :

1. Untuk input graf1 dapat dilihat bahwa output simulasi memberikan hasil yang berbeda untuk kedua algoritma, diperlukan 6 warna untuk algoritma Dsatur dan 5 warna untuk algoritma Vertex Merge, itu berarti diperlukan 6 channel untuk algoritma Dsatur dan 5 channel untuk algoritma Vertex Merge, yaitu:

a. Algoritma Dsatur:

- channel 1 untuk AP1 dan AP5

- channel 4 untuk AP7 dan AP9

- channel 7 untuk AP3 dan AP4

- channel 9 untuk AP2 dan AP8

- channel 11 untuk AP10
- channel 13 untuk AP6

b. Algoritma Vertex Merge :

- channel 1 untuk AP1 dan AP2

- channel 4 untuk AP3 dan AP4

- channel 7 untuk AP5 dan AP6

- channel 10 untuk AP7 dan AP9

- channel 13 untuk AP8 dan AP10

2. Untuk input graf2 dapat dilihat bahwa output simulasi memberikan hasil yang berbeda untuk kedua algoritma, diperlukan 8 warna untuk algoritma Dsatur dan 7 warna untuk algoritma Vertex Merge, itu berarti diperlukan 8 channel untuk algoritma Dsatur dan 7 channel untuk algoritma Vertex Merge, yaitu:

a. Algoritma Dsatur: 
- channel 1 untuk AP1 dan AP4

- channel 3 untuk AP2 dan AP11

- channel 5 untuk AP9 dan AP14

- channel 7 untuk AP5 dan AP10

- channel 9 untuk AP6 dan AP7

- channel 11 untuk AP8

- channel 12 untuk AP12 dan AP13

- channel 13 untuk AP3

b. Algoritma Vertex Merge:

- channel 1 untuk AP1 dan AP4

- channel 3 untuk AP2 dan AP3

- channel 5 untuk AP5 dan AP6

- channel 7 untuk AP7 dan AP8

- channel 9 untuk AP9 dan AP10

- channel 11 untuk AP11 dan AP12

- channel 13 untuk AP13 dan AP14

3. Untuk input graf3 dapat dilihat bahwa output simulasi memberikan hasil yang berbeda untuk kedua algoritma, diperlukan 8 warna untuk algoritma Dsatur dan 6 warna untuk algoritma Vertex Merge, itu berarti diperlukan 8 channel untuk algoritma Dsatur dan 6 channel untuk algoritma Vertex Merge, yaitu:

a.Algoritma Dsatur:

- channel 1 untuk AP1, AP6 dan AP13

- channel 3 untuk AP5, AP10 dan AP15

- channel 5 untuk AP2, AP9 dan AP14

- channel 7 untuk AP11 dan AP17

- channel 9 untuk AP4 dan AP7

- channel 11 untuk AP3 dan AP8

- channel 12 untuk AP16

- channel 13 untuk AP12

b. Algoritma Vertex Merge:

- channel 1 untuk AP1, AP4 dan AP7

- channel 4 untuk AP2, AP5 dan AP8

- channel 7 untuk AP3, AP6 dan AP9

- channel 9 untuk AP10, AP13 dan AP16

- channel 11 untuk AP11, AP14 dan AP17
- channel 13 untuk AP12 dan AP15

Dari tabel perbandingan antara algoritma Dsatur dan algoritma Vertex Merge diatas dapat buat grafik perbandingannya seperti terlihat pada

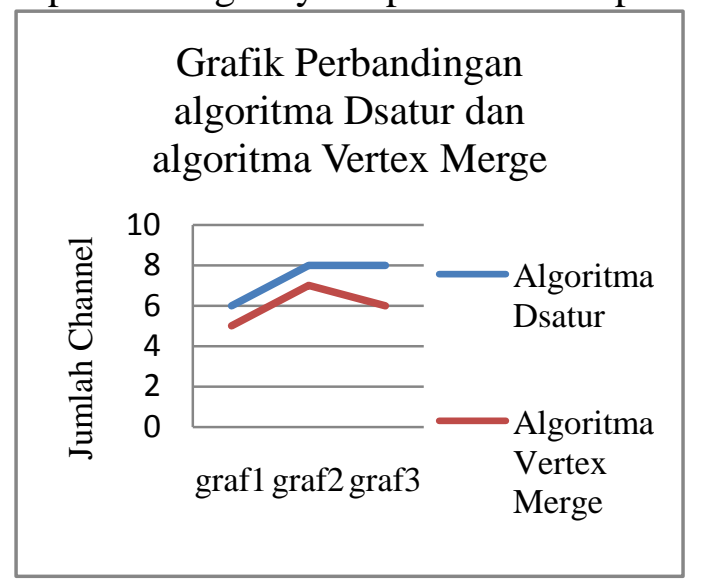

gambar 5 dibawah ini:

Grafik 1. Grafik perbandingan algoritma Dsatur dan algoritma Vertex Merge

\section{Kesimpulan}

Hasil dari simulasi tiga buah graf yang sudah dilakukan dapat dilihat bahwa dengan menggunakan algoritma Dsatur diperlukan 6 channel untuk graf1, 8 channel untuk graf2 dan graf3. Sedangkan dengan menggunakan algoritma Vertex Merge diperlukan 5 channel untuk graf1, 7 channel untuk graf2 dan 6 channel untuk graf3. Dari hasil ini dapat disimpulkan bahwa algoritma Vertex Merge berhasil memberikan jumlah channel yang diperlukan lebih sedikit dibandingkan dengan algoritma Dsatur, yang berarti bahwa algoritma Vertex Merge lebih baik dibandingkan dengan algoritma Dsatur.

\section{Daftar Pustaka}

Al Mamun, K.M.A. dkk. 2009. An Efficient Variable Channel Allocation Technique for WLAN IEEE 802.11 Standard, in Proceedings Conference on Circuits, 
Communication and System, pp.9295.

André, M., G. Pesant dan S. Pierre, 2005.

A Variable Neighborhood Search Algorithm for Assigning Cells to Switches in Wireless Networks. J. Comput. Sci., 1: 175-181.

Brelaz, D. 1979. New Methods to Color the Vertices of a graph, on Communication of the ACM, no.22, pp.251-256

Diestel, R., 2006. Graph Theory (Graduate Texts and Mathematics). 3rd Edn., Springer, USA., ISBN:10: 3540261834, pp: 415.

Duan, Z. dkk. 2010 Optimal Channel Assignment for Wireless Networks Modelled as Hexagonal and Square Grids. International Conference on Networks Security Wireless Communications and Trusted Computing.

Handrizal,dan Heri Santoso, 2012. Algoritma vertex merge untuk menentukan alokasi channel pada akses point wireless LAN. Seminar Nasional Ilmu Komputer 2012

Juhos dan Jano, I. 2006. Increasing the efficiency of graph coloring algorithms with a representation based on vector operations. J. Software, pp: 1.

Ming, H. dkk. 2009. Hierarchical genetic algorithm for dynamic channel units allocation in td-cdma/tdd system. International Journal of Wireless \& Mobile Networks (IJWMN), Vol 1, No 2. pp.103-116.

Riihijarvi, J. dkk. 2006. Performance Evaluation of Automatic Channel Assignment Mechanism for IEEE 802.11 Base on Graph Coloring, in Proceedings The $17^{\text {th }}$ Annual IEEE International Symposium on Personal, Indoor and Mobile Communications, pp.1-5. 